who write upon the progress of plant life on the globe, I take the liberty of reporting briefly what we really know in regard to the cretaceous flora of the North American continent.

Some twenty years ago numerous impressions of angiospermous leaves were brought by Dr. Hayden and myself from the group of sandsiones which lie at the base of cur cretaceous system. Outìne sketches of a part of these were sent by Mr. Meek to Prof. Heer, of Zurich. I le pronounced them miocene tertiary. To this conclusion he was led by their high botanical rank, their generic affinities with miocene plants, and the supposed identity of some of them with miocene species.

The announcement of Prof. Heer's decision led to a somewhat earnest discussion, in which Frof. Heer, M. J. Marcou, and Mr. Leo Lesquereux supported the view that the plants in question were tertiary, while Messrs. Meek and myself asserted that they were cretaceous, because the strata which contain them are overlain by more than 2,000 feet of limestones filled with characteristic cretaceous fossils, a number of which are identical with those found in the gault and chalk of Europe. An end was finally put to this debate by M. Marcou and Prof. Capellini, of Bologna, gning to Kansas and collecting a large number of these leaves from beds overlain by unmistakable cretaceous strata. The true position of this flora was then not only acknowledged but proclaimed by these gentlemen, and since that time every geologist in America has accepted the statement which I made in my letter to Messrs. Meek and Hayden in $\mathbf{1} 85^{8}$, and in my article on the Ancient Vegetation of North America (American Fournal of Science, vol. xxix, I860, p. 208), that "the American flora assumed nearly the botanical character it now has in the cretaceous age, and that our lower cretaceous rocks contain the remains of sixty or seventy species of angiospermous trees, many of which belong to our most commion living genera, such as Quercus, Salix, Marnolia, Platanus, Liriodendron, Fagus, Alnus, Iiquidambar, \&cc."

Since the settlement of this question a large number of additions have been made to the then known species of this flora, and it is probably not too much to say that we have obtained leaves of nearly one hundred species of angiospermous trees from the base of our cretaceous system, the equivalent of the upper greensand of England.

All the leaves figured in Lesquereux's "Fossil Flora of the Western Territories," part I., were obtained from this horizon, and a large number of additional species have been described by Prof. Heer in his "Phyllites Cretacea," or by myself in "Our Later Extinct Floras," while many others yet wait publication.

The plants of our upper cretaceous and tertiary rocks have not yet been fully described, and there is some difference of opinion as to where the line should be drawn between these two systems, but it is quite certain that a large part of the species described by Mr. Lesquereux from the "lignite beds," and referred by hirn to the tertiary, are really cretaceous; not only because they are associated with Ammonites, Inoceramus, and other cretaceous fossils, but because the strata which contain them underlie unconformably the Coryphodon beds, the base of our eocene. Whatever shall be ultimately decided in regard to the line of separation between our later cretaceous and earlier tertiary strata, this will in no wise affect our conclusions in regard to the general facies of the American cretaceous flora. The statements made many years since are confirmed by ali fresh evidence, and now stand unquestionable, that between the trias and the chalk-we know nothing of our Jurassic florathe vegetation of North America was revolutionised, and that at the beginning of our cretaceous age it had assumed essentially the character and consisted chiefly of the same generic elements that it exhibits now.

I may also add that up to the present time no species of $\mathrm{Am}$ monites, Baculites, or Inoceramus have yet been found in America above the cretaceous system; and that so far as we now know, these genera are as decisive of the age of the strata which contain them here as in the Old World.

Columbia College, New York, June ig

\section{Meteorological Notes from Lisbon}

THE following meteorological notes, compiled in great part from the daily bulletins of the Observatorio Real of Lisbon, supplemented by observations made by myself, by means of a Casella's self-registering thermometer and a good aneroid barometer, during a seven months' residence in that city, may not be without some value to weather observers. I arrived on
October 15, consequently the observations for this month refer only to the latter half. The records were made at $9 \mathrm{~A} . \mathrm{M}$. and at 5 P.M. To save space the readings will be given throughout (except for October) in the following order:-I. Barometer (reduced to sea-level), $(a)$ the average of observations taken at $9 \mathrm{~A} . \mathrm{M},(b)$ the highest, and (c) the lowest reading of the month. II. Thermometer (Fahrenheit), $(a)$ average of daily observations made ai 9 A.M., (b) average of the highest, and $(c)$ of the lowest readings in the twenty-four hours; $(d)$ the hirhest, and $(e)$ the lowest reading of the month. III. Direction of Wind: N.S. E. iV. represent the directions indicated, or any point thereof, after which the number of days is given on which it blew from that quarter. IV. The rain of the month is stated in inches.

OCTOBER, 1876 .- The morning temperatures ranged from $54^{\circ} \mathrm{F}$. to $70^{\circ}$; midday, from $62^{\circ}$ to $80^{\circ}$; and evening, $53^{\circ}$ to $72^{\circ}$; the average of the night temperature for the half-month, 52.2 ; and the average rainfall for the same period was 3.8 inches. No wind record was kept.

November, 1876 .- I. (a) $29^{\circ} 95,(b) 30^{\prime} 44$, (c) $29^{\circ} 44^{4}$. This last reading is the record of the $\mathrm{I} 2 \mathrm{th}$, and was accompanied by a terrific gale from the south-west, which wrought much damage both on land, on the river, and at sea. Several residents, who were not unfamiliar with earihquake shocks, averred that they felt a distinct tremor of the earth about 4 A.M., at which time the barometer registered 29 inches. In the Bay of Biscay on the same morning the lowest point reached by the mercury was $28 \cdot 25$, as I was, I believe accurately, informed by the captain of a Glasgow steamer which arrived in the Tagus some days later. II. (a) $57^{\circ} 59,(b) 63^{\circ} \cdot 9$ (c) $54^{\circ} \circ 9$ (d) $70^{\circ} .98$ (c) $46^{\circ}$. III. N. 7 days, S. 10, E. 7, W. 2 ; of 3 days no record. IV. Rain, Io inches, which fell on 17 days. This was one of the most rainy Novernbers for many years. The rainfall of the year 1874 was 17.2 , and that of $1875,18.3$ inches. The total amounts for the months of November from $1873-1875$ was 5.5 inches. The mean of this month for the last twenty years is 4.3 inches. Most destructive floods occurred during the month.

DACEMBER, 1876 . - I. (a) $29^{\circ} 96$, (b) $30^{\circ} 3$, (c) $29^{\circ} 4$ inches. II. (a) $54^{\circ} \cdot 8,\left(\right.$ b) $59^{\circ} 5$, (c) $51^{\circ} 6$, (d) $65^{\circ} \cdot 5$, (e) $44^{\circ} \cdot 2$. III. N. 5, S. 18 , E. o, W. 5 , calm 3 days. IV. Rain $19^{\circ} 19$ inches on 28 days, greatest fall on 1 day $(6 \mathrm{th}) 3^{\cdot} 2$ inches, and least 1003

JANUARY, 1877.- I. (a) 30.18, (b) 30.58, (c) 29.54 inches. II. (a) $52^{\circ \circ} 93,(b) 58^{\circ} .96$, , (c) $50^{\circ} \cdot 8$, (d) $65^{\circ} \cdot 66$, , (c) $44^{\circ}$. III. N. I7, S. 9, E. O, W. 3, calm 2 days. IV. Rair which fell on 14 davs, 7.007 inches ; from $x$ st to Ioth, 6.0609 inches.

FEBRUARY, 1877 .--I. (a) 30.35, (b) 30.54, (c) 29.92 inches. II. $(a) 52^{\circ},(b) 56^{\circ} \cdot 64,\{c) 48^{\circ} \cdot 29,(d) 67^{\circ} 38,(c) 42^{\circ} \cdot 9$ (the lowest temperature of the seven months). III. N. $25, \mathrm{~S}, \mathrm{I}, \mathrm{E} . \mathrm{I}, \mathrm{W}$. 0 , calm 1 day. IV. Rain, which fell on 2 days, $I$ ' 28 inches.

MARCH, I877. - I. (a) 29.94, (b) $30^{\circ} 39$, (c) $29^{\circ} 36$ inches. II. (a) $47^{\circ} \cdot 63$, (b) $59^{\circ} \cdot 34$, (c) $48^{\circ} \cdot 5$, (d ) $71^{\circ} \cdot 6$, (e) $43^{\circ} \cdot 3$. III. N. 10, S. 9, E. I, W. 6, calm 1 , of 4 days no record. IV. Rain, which fell on 13 days, 2.5 inches.

APRIL, 1877.-I. (a) $29^{\circ} .2$ (b) $30^{\circ} \mathrm{I}_{3}$, (c) 29.60 inchez. II. (a) $65^{\circ} \cdot 5(b) 62^{\circ} \cdot 9$, (c) $51^{\circ} \cdot 9$, (d) $71^{\circ} 7,\left(\right.$ e) $48^{\circ} \cdot 2$. III. N. 8, S. 8, E. 1, W. II, 2 days linrecorded. IV. Rain in 17 days, $6 \cdot 5$.

I would draw the attention of those threateried with bronchial or pulmonary complaints to this locality as a winter and spring refuge. The site of the city of Lisbon is finely chosen, facing almost due south, and the position of the principal part of the town in which the chief hotels are, is nearly sheltered from the northerly and easterly winds by surrounding heights. It is of easy access from England- 3 days, and sometimes fewer, from Southampton by a royal mail steamer. Fires are rarely to be seen in a Portuguese sitting-room, and during the seven months of my sojourn there it was necessary only once or twice to have one in our room for an invalid's sake. I had an opportunity of seeing many sufferers both tw route for, and again returning to England from, Madeira. Some of them complained much of the weather experienced there, and said how they wished they lrad remained in, Lisbon, where the climate seemed equally to suit them, and where they should have had at least more comforts, more cheerful society, and more varied means for killing the Enemy-time.

HENRY O. FORBES

\section{Fertilisation of Flowers by Insects}

IN my last article on Alpine Gentiana species, I supposed that the chief, if not the only fertiliser of $G$. bavarica and verna might be Macroglossa stellatarum with its proboscis of $25.28 \mathrm{~mm}$. 